\title{
Suspension Effect of the TSB BK Prosthesis : A Comparison with the PTB BK Prosthesis
}

\author{
Hiroshi Narita, ${ }^{* 1}$ Kazutoshi YokogushI ${ }^{* 1}$ Seiichi IshII, ${ }^{* 1}$ \\ Masafumi Kakizawa, ${ }^{* 1}$ Toshiya Nosaka, ${ }^{* 2}$ Yoshihiro Nakamura ${ }^{* 3}$
}

TSB 下腿義足の懸垂効果

-PTB 下腿義足との比較一

成田寛志*1 横串算敏*1 石井清一*1

柿澤雅史*1 野坂利也*2 中村嘉宏*3

\begin{abstract}
要 旨：ICEROSS システムを併用したTSB 下腿義足と PTB 下腿義足の懸垂効果をX 線 計測にて比較した。懸垂効果は懸垂時と荷重時の脛骨移動距離を計測した。TSB 式下腿義足 の懸垂効果は $2.53 \pm 0.90 \mathrm{~cm}$ で PTB下腿義足の $3.60 \pm 0.56 \mathrm{~cm}$ より優れていた（ $p<$ 0.05)。また, 断端部に疼痛のある症例や軟部組織の多い症例では TSB 下腿義足の䀣垂効果 は減少したが, スタンプソックスの使用により, PTB 下腿義足よりも高い満足感が得られた。 (リハ医学 $1997 ; 34: 418-421$ )
\end{abstract}

\begin{abstract}
X-ray measurements were used to compare the suspension effect of a TSB below-knee prosthesis with an ICEROSS system to that of a PTB below-knee prosthesis. The suspension effect was measured as the movement of the tibia between the suspension position and the weight-bearing position. The suspension effect of the TSB prosthesis $(2.53 \pm 0.90 \mathrm{~cm})$ was superior to that of the PTB prosthesis $(3.60 \pm 0.56 \mathrm{~cm}) \quad(p<0.05)$. Although the suspension effect of the TSB prosthesis was less effective in reducing tibial movement in cases with stump pain or an abundance of soft tissue, a higher level of satisfaction was obtained by using the TSB prosthesis with stump socks than by using the PTB prosthesis. (Jpn J Rehabil Med 1997; $34: 418-421$ )
\end{abstract}

Key words : total surface bearing below-knee prosthesis (TSB 下腿義足), icelandic roll on silicone socket: ICEROSS (シリコーン製内ソケット), suspension effect (懸垂効果)

\section{Introduction}

The use of a total surface-bearing (TSB) belowknee prosthesis with an Icelandic roll-on silicone socket (ICEROSS) ${ }^{1)}$ has recently become popular in prosthetics. This new below-knee prosthesis does not require the knee cuff that is used as a suspension device in the conventional PTB prosthesis. Due to the great amount of friction between the silicone socket and skin in the TSB prosthesis, there is a reduction in the piston motion when the heel is on the ground and an increase in the flexion angle of the knee in the swinging phase. ${ }^{2)}$ The feeling of stability and of secure attachment are also superior

Received November 27, 1996 ; Accepted March 26, 1997

${ }^{* 1}$ Division of Rehabilitation, ${ }^{* 3}$ Division of Radiology, Sapporo Medical University/South-1 West-17, Chuo-ku, Sapporo 060, Japan 札幌医科大学リハビリテーション部*1, 放射線部*3/テ 060 札幌市中央区南 1 条西 17 丁目

${ }^{* 2}$ Nosaka Prosthetics and Orthotics Co. Ltd./South-3 East-4, Chuo-ku, Sapporo 060, Japan 野坂義肢製作所/ $\mathrm{T} 060$ 札幌市中央区南 3 条東 4 丁目 
in the TSB prosthesis.

However, there have been no reports presenting objective measurements that confirm the superiority of the suspension effect of the TSB prosthesis compared to that of the PTB prosthesis. Therefore, in the present study, we 1) performed a comparative radiological evaluation of the suspension effect between TSB and PTB prostheses, and 2) investigated the factors affecting the suspension effect of the TSB prosthesis (stump pain, amount of soft tissue in the stump, and the use of stump socks between the stump and the ICEROSS silicone socket).

\section{Subjects}

The subjects were nine below-knee amputees (10 limbs), including eight men and one woman, aged 19-74 years (mean 33.9 years). The reasons for amputation were traumatic injuries in 6 cases $(6$ limbs), tumors in 2 cases (2 limbs), and burns in 1 case (2 limbs). The length of amputation was 13-29 $\mathrm{cm}$ (mean: $19.8 \mathrm{~cm}$ ). All the subjects had previously used a PTB prosthesis temporarily or perma- nently before changing to the present TSB prosthesis for everyday use. The period of TSB prosthesis use was from 6 months to 2 years and 11 months (mean: 1 year and 4 months).

With TSB prosthesis, stump socks are sometimes used between the stump and the ICEROSS silicone socket in cases where there are problems such as stump pain, sweat retention or unsatisfactory fitting. Among the present subjects, stump- socks were used between the stump and socket in 5 out of 10 limbs. The reasons for using the stump socks were to alleviate pain ( 2 cases), prevent retention of sweat ( 2 cases), and improve socket fitting (1 case).

\section{Methods}

Lateral-view X-rays were taken in the one-leg standing position while wearing the PTB prosthesis or TSB prosthesis in the weight-bearing and suspension positions. For the suspension phase, a $5-\mathrm{kg}$ load was applied to the foot of the prosthesis and an Xray was taken with the prosthesis suspended at a knee flexion angle of $30^{\circ}$. For the X-ray measurement, the distance between the end of the tibia and
PTB

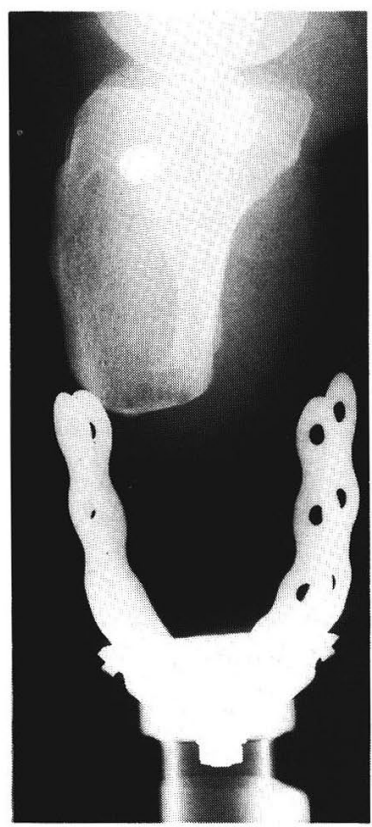

suspension

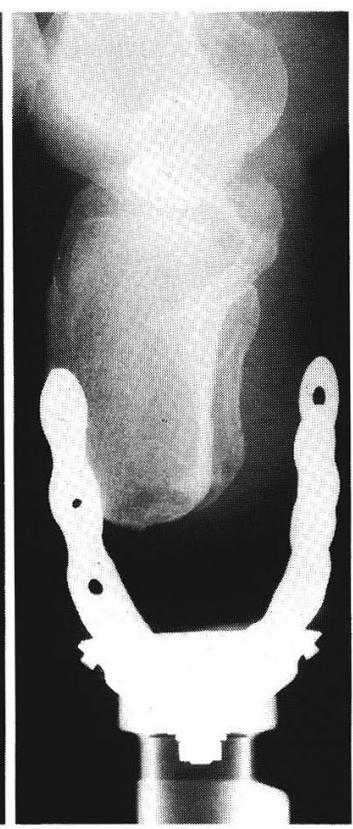

weight-bearing

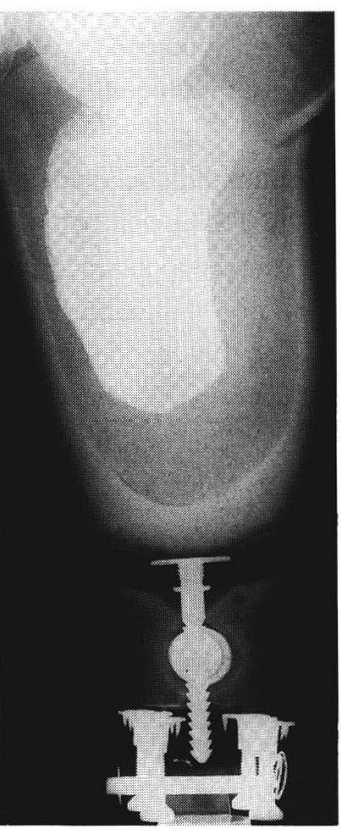

suspension
TSB

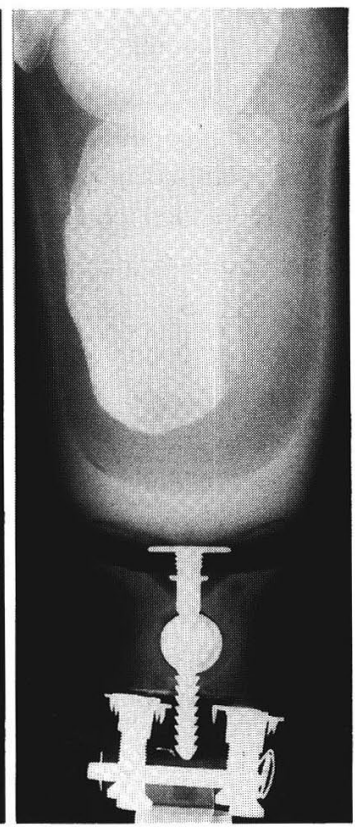

weight-bearing

Fig. 1 Lateral-view X-rays of the PTB and the TSB prosthesis during attachment 
Table 1 Comparison of PTB and TSB Suspension Effects

\begin{aligned} \hline PTB & $3.60 \pm 0.56(\mathrm{~cm}) \\$ TSB & $2.53 \pm 0.90(\mathrm{~cm}) \\$\hline$n=10, p<0.05 & \end{aligned}$

the base of the socket was measured, and the movement of the stump was calculated by subtracting the value in the weight-bearing position from the value in the suspension position (Fig. 1). For the TSB prosthesis, the height of the gap between the stump soft tissue and the base of the socket was measured in the suspension position, and the measurements were compared between cases with 1) pain and no pain in the stump, 2) a large and small amount of soft tissue, and 3) use and non-use of stump socks.

\section{Results}

\section{Comparison of the suspension effect between} TSB and PTB prostheses

The movement of the end of the tibia between the suspension position and weight-bearing phase was 2 . $53 \pm 0.90 \mathrm{~cm}$ for the TSB prosthesis and $3.60 \pm 0.56$ $\mathrm{cm}$ for the PTB prosthesis. The movement for the TSB prosthesis was significantly lower $(p<0.05$, Table 1), meaning that the suspension effect of the TSB prosthesis was superior to that of the PTB prosthesis.

2. Relationship between stump pain, amount of stump soft tissue and the TSB prosthesis

The stump movements in the two cases with stump pain were $7.0 \mathrm{~cm}$ and $4.4 \mathrm{~cm}$, and in the two cases with a large amount of soft tissue, they were $4.0 \mathrm{~cm}$ and $2.6 \mathrm{~cm}$. These values were larger than the mean stump translation of $2.53 \mathrm{~cm}$ in TSB prostheses. Thus, there was a tendency for the movement to increase in cases with stump problems.

3. Alteration to the suspension effect through the use/non-use of stump sock

The height of the stump gaps in TSB prostheses were measured in the suspension phase, both with and without the use of a stump sock, and the values were compared. The stump gap was significantly larger in the 'stump socks' group $(2.38 \pm 0.76 \mathrm{~cm})$ than in the 'no stump socks' group $(0.38 \pm 0.41 \mathrm{~cm})$ $(p<0.001)$.

\section{Discussion}

Lilja et al. ${ }^{3)}$ estimated the mean tibial movement for walking with a PTB prosthesis to be $2.8 \mathrm{~cm}$. This value is smaller than the result we obtained $(3.60 \pm 0.56 \mathrm{~cm})$ for the PTB prosthesis with a $5-\mathrm{kg}$ load applied during the swinging phase to simulate the estimated centrifugal force acting on the prosthesis. However, in the present study an even smaller movement $(2.53 \pm 0.90 \mathrm{~cm})$ was obtained for the TSB prostheses with a 5 - $\mathrm{kg}$ load applied, indicating that the TSB prosthesis has a superior suspension effect.

According to Tazawa, ${ }^{4}$ the characteristics of the suspension of a TSB prosthesis with an ICEROSS silicone socket produce an improvement in the feeling of fitness and lightness, which means an improvement in the feeling of stability during the standing phase and secure attachment during the swinging phase. The results of the X-ray measurements conducted in the present study clearly show that the suspension effect of the TSB prosthesis is superior to that of the conventional PTB prosthesis, and this improved suspension effect supports the feeling of securer attachment during the swinging phase.

Some demerits of the TSB prosthesis have been pointed out, such as a feeling of pulling and retention of sweat on the stump due to the ICEROSS silicone socket. However, these demerits can be overcome by using a stump sock between the stump and the ICEROSS silicone socket or by redesigning the socket. Although the use of a stump sock allows the inflow of air which widens the gap between the stump and socket, the subjects who used stump socks in this study were more satisfied with the TSB prosthesis than the PTB prosthesis, and none of the subjects changed back to the original PTB prosthesis. Thus, although the use of a stump sock lowered the suspension effect of the TSB socket, the subjects who used the TSB prosthesis with stump socks expressed a high level of satisfaction. The higher level of satisfaction obtained from using the TSB prosthesis with the ICEROSS silicone socket can be attributed not only to the superior suspension effect but also to the improved stability in the standing phase compared with the PTB prosthesis. 


\section{Conclusions}

1. The suspension effect of the TSB prosthesis with an ICECROSS silicone socket is superior to that of the PTB prosthesis.

2. Although the suspension effect of the TSB prosthesis is lower in cases with stump pain or abundant soft tissue, the use of a stump sock can resolve these problems, and the level of satisfaction from using the TSB prosthesis with a stump sock is higher than that from using the conventional PTB prosthesis.

\section{References}

1) Kristinsson $O$ : The ICEROSS concept: a discussion of a philosophy. Prosthet Orthotics Int 1993; 17: $49-55$

2) Yokogushi K, Narita H, Takiuchi T, Yamashita $T$, Nosaka T: A comparative study between TSB below-knee prosthesis with ICEROSS system and PTB below-knee prosthesis. Jpn J Rehabil Med 1996; 33: 488-491 (in Japanese)

3) Lilja M, Johansson T, Oberg T: Movement of the tibial end in a PTB prosthesis socket a sagittal Xray study of the PTB prosthesis. Prosthet Orthotics Int $1993 ; 17: 21-26$

4) Tazawa E: The TSB socket and silicone suction sleeve concept. Jpn J Prosthet Orthotics 1991; 7 : $145-150$ (in Japanese) 